\title{
Review
}

\section{Nitrogen Fertilizer Management Strategies for Rice Production in Bangladesh}

\author{
Abu Turab Mohammad Ali Choudhury ${ }^{a b *}$, Mohammad Abu Saleque ${ }^{a}$, Shafiuddin Kaisar Zaman ${ }^{a}$, \\ Nurul Islam Bhuiyana, Abdul Latif Shah a and Mohammad Shamsur Rahman ${ }^{\mathrm{a}}$ \\ ${ }^{a}$ Soil Science Division, Bangladesh Rice Research Institute, Gazipur 1701, Bangladesh \\ ${ }^{b}$ SUNFix Centre for Nitrogen Fixation; Faculty of Agriculture and Environment, Biomedical Building, \\ 1 Central Avenue, Australian Technology Park, University of Sydney, Eveleigh, NSW 2015, Australia
}

(received November 22, 2012; revised December 31, 2012; accepted January 4, 2013)

\begin{abstract}
Various ways of increasing nitrogen (N) fertilizer use efficiency in rice culture has been evaluated by conducting field experiments at Bangladesh Rice Research Institute (BRRI). Nitrogen fertilizer use efficiency in rice culture can be increased by root-zone application of modified forms of urea like urea large granule (ULG) and urea super granule (USG). The efficiency of urea-N can be increased to some extent even by injection of the conventional prilled urea (PU) into the root-zone of the rice plant by the instrument "Pneumatic Urea Injector". Application of sulphur (S) along with $\mathrm{N}$ increases $\mathrm{N}$ use efficiency in rice culture in $\mathrm{S}$ deficient soils. Modern rice varieties having relatively taller plant stature can exploit more soil $\mathrm{N}$ for grain production compared to short statured varieties. Different varieties require different amounts of $\mathrm{N}$ for maximum grain yield and it is important to note it to avoid indiscriminate application of a single $\mathrm{N}$ rate for all the varieties.
\end{abstract}

Keywords: nitrogen fertilizer, rice production, environmental pollution control

Rice is the major cereal crop in Bangladesh. With increase in population, the demand for rice is increasing over the years. With intensive research rice yield per unit area has increased gradually over the years (Table 1). Consequently fertilizer consumption especially $\mathrm{N}$ fertilizer has also been increased gradually (Table 2). Nitrogen $(\mathrm{N})$ is a primary nutrient for all crops. Rice crop requires large amount of $\mathrm{N}$ for its growth, development and grain production (Sahrawat, 2000). Generally rice plant removes around $14-20 \mathrm{~kg} \mathrm{~N}$ to produce one tonne of rough rice including straw (Table 3). Most of the rice soils of the world are deficient in $\mathrm{N}$, and biological nitrogen fixation by Cyanobacteria and diazotrophic bacteria can only meet a fraction of the $\mathrm{N}$ requirement (Sattar et al., 2008; Hashem, 2001; Baldani et al., 2000). Thus, fertilizer $\mathrm{N}$ application is essential to meet the crop requirement. But, the efficiency of added fertilizer $\mathrm{N}$ in rice culture depends on $\mathrm{N}$ sources, application method, rate of $\mathrm{N}$ as well as management practices as evidenced by the ${ }^{15} \mathrm{~N}$ tracer studies (Wang et al., 2011; Chen et al., 2010; Wang et al., 2008). Prilled urea (PU) is applied as N source for rice but the efficiency of added $\mathrm{N}$ from $\mathrm{PU}$ is very low, generally it is around $30-45 \%$ and in many cases even much lower as determined by the ${ }^{15} \mathrm{~N}$ tracer technique (Table 4). *Author for correspondence;

E-mail: atmachoudhury@hotmail.com; bPresent address
This low $\mathrm{N}$ use efficiency in rice culture is attributed mainly to denitrification, ammonia volatilisation and leaching losses (Hakeem et al., 2011; Mai et al., 2010; Zhao et al., 2010; Choudhury and Kennedy, 2005). Ammonia volatilisation and denitrification cause atmospheric pollution through the production of greenhouse gases like nitrous oxide, nitric oxide and ammonia (Choudhury and Kennedy, 2005; Reeves et al., 2002). Nitrous oxide absorbs infrared radiation and depletes the stratospheric ozone layer. Nitric oxide causes acid deposition by forming nitric acid. Leaching causes nitrate toxicity in the groundwater. High nitrate toxicity in the groundwater causes human health problems (Shrestha and Ladha, 1998). These problems are of great concern to the agronomists, soil and environmental scientists and policy makers around the world. Appropriate strategies should be taken to reduce $\mathrm{N}$ losses and thereby minimize these environmental problems. In this regard, research has been conducted around the world in several research organizations including Bangladesh Rice Research Institute (BRRI). This paper reviews some salient findings of BRRI already published in different journals to accumulate the information altogether indicating $\mathrm{N}$ fertilizer management strategies for sustainable rice production and control of environmental pollution problems. 
Table 1. Population, rice cropped area, rice production and yield in Bangladesh over the years since 1960

\begin{tabular}{|c|c|c|c|c|c|c|c|}
\hline \multirow[t]{2}{*}{ Year } & \multirow{2}{*}{$\begin{array}{l}\text { Population } \\
\text { (million) }\end{array}$} & \multirow{2}{*}{$\begin{array}{l}\text { Rice cropped } \\
\text { area (000 ha) }\end{array}$} & \multirow{2}{*}{$\begin{array}{l}\text { Paddy } \\
\text { production } \\
\text { (000 tonnes) }\end{array}$} & \multicolumn{2}{|c|}{ Paddy yield } & \multirow{2}{*}{$\begin{array}{l}\text { Rice production } \\
\text { (kg/person) }\end{array}$} & \multirow{2}{*}{$\begin{array}{l}\text { Rice available } \\
\text { excluding import } \\
\text { (g/person/day) }\end{array}$} \\
\hline & & & & $\mathrm{t} / \mathrm{ha}$ & $\mathrm{kg} /$ person & & \\
\hline 1960 & 51.585 & 8857 & 14522 & 1.64 & 282 & 197 & 540 \\
\hline 1970 & 66.671 & 9912 & 16731 & 1.69 & 251 & 176 & 481 \\
\hline 1980 & 88.219 & 10309 & 20844 & 2.02 & 236 & 165 & 453 \\
\hline 1990 & 109.820 & 10435 & 26781 & 2.57 & 244 & 171 & 468 \\
\hline 2000 & 129.194 & 10887 & 37633 & 3.46 & 291 & 204 & 559 \\
\hline 2010 & 153.437 & 11800 & 48455 & 4.11 & 316 & 221 & 606 \\
\hline
\end{tabular}

The population data was collected from the website http://www.populstat.info/Asia/bangladesh.htm. The data on rice cropped area and paddy (un-milled rice) production have been collected from the USDA database available in the IRRI website (IRRI, 2011). Paddy yield per person was converted to rice (milled rice) yield considering $70 \%$ milling outturn which is average of varieties (BRRI, 2000).

Table 2. Consumption of fertilizer N, P and K in Bangladesh over the years since 1961

\begin{tabular}{llll}
\hline \hline \multirow{2}{*}{ Year } & \multicolumn{3}{c}{ Fertilizer consumption (000 tonnes) } \\
\cline { 2 - 4 } & $\mathrm{N}$ & $\mathrm{P}$ & $\mathrm{K}$ \\
\hline 1961 & 20.0 & $\mathrm{DNA}$ & 1.5 \\
1970 & 99.2 & 34.0 & 10.4 \\
1980 & 266.2 & 118.4 & 28.7 \\
1990 & 609.2 & 231.8 & 90.0 \\
2000 & 995.8 & 250.3 & 143.0 \\
2010 & 1275.0 & 420.0 & 220.3 \\
\hline \hline
\end{tabular}

Source: IFA, 2011; DNA = data not available.

Table 3. N, P, K and S removal of four rice varieties

\begin{tabular}{llllllll}
\hline \hline $\begin{array}{l}\text { Rice } \\
\text { variety }\end{array}$ & $\begin{array}{l}\text { Grain } \\
\text { yield } \\
(\mathrm{t} / \mathrm{ha})\end{array}$ & \multicolumn{2}{l}{$\begin{array}{l}\text { Total amount of nutrients (kg) } \\
\text { removed by grain and straw }\end{array}$} & \multicolumn{2}{c}{ Reference } \\
\cline { 3 - 6 } & & $\mathrm{N}$ & $\mathrm{P}$ & $\mathrm{K}$ & $\mathrm{S}$ & \\
\hline BR1 & 4.2 & 19.76 & 3.10 & 21.43 & 1.90 & $\begin{array}{l}\text { Choudhury } \\
\text { et al., 1992 }\end{array}$ \\
BR3 & 5.6 & 13.93 & 3.39 & 20.89 & 2.14 & $\begin{array}{l}\text { Choudhury } \\
\text { et al., 1994c }\end{array}$ \\
BR11 & 5.2 & 17.69 & 3.08 & 22.31 & 1.92 & $\begin{array}{l}\text { Choudhury } \\
\text { et al., 1994c }\end{array}$ \\
BR22 & 4.6 & 15.65 & 2.83 & 19.13 & 1.96 & $\begin{array}{l}\text { Choudhury } \\
\text { et al., 1992 }\end{array}$
\end{tabular}

Sources and forms of nitrogen fertilizer. Now-a-days different sources and forms of $\mathrm{N}$ fertilizer are available in the market for commercial use. The most commonly used $\mathrm{N}$ fertilizer for rice crop is prilled urea (PU). Urea super granule (USG) is a modified form of urea having an average diameter of $11.5 \mathrm{~mm}$. It has been developed
Table 4. Fertilizer N uptake and recovery of MR185 rice in different soils as determined by the ${ }^{15} \mathrm{~N}$ tracer technique

\begin{tabular}{|c|c|c|c|c|}
\hline \multirow[t]{2}{*}{ Soil series } & \multirow[t]{2}{*}{$\begin{array}{l}\text { Fertilizer } \\
\mathrm{N} \text { applied } \\
(\mathrm{kg} / \mathrm{ha})\end{array}$} & \multicolumn{2}{|c|}{$\begin{array}{l}\mathrm{N} \text { uptake }(\mathrm{kg} / \mathrm{ha}) \text { by } \\
\text { whole plant (grain and } \\
\text { straw) }\end{array}$} & \multirow[t]{2}{*}{$\begin{array}{l}\text { Fertilizer } \\
\mathrm{N} \text { recovery } \\
(\%)\end{array}$} \\
\hline & & $\begin{array}{l}\text { Total N } \\
\text { uptake }\end{array}$ & $\begin{array}{l}\text { Fertilizer N } \\
\text { uptake }\end{array}$ & \\
\hline \multirow[t]{3}{*}{ Guar } & 40 & 96.53 & 6.40 & 16 \\
\hline & 80 & 133.21 & 18.49 & 23 \\
\hline & 120 & 151.68 & 28.50 & 24 \\
\hline \multirow[t]{3}{*}{ Hutan } & 40 & 54.39 & 8.02 & 20 \\
\hline & 80 & 54.94 & 13.94 & 17 \\
\hline & 120 & 47.66 & 14.22 & 12 \\
\hline \multirow[t]{3}{*}{ Idris } & 60 & 67.82 & 23.74 & 40 \\
\hline & 120 & 90.37 & 48.62 & 41 \\
\hline & 180 & 116.75 & 74.44 & 41 \\
\hline \multirow[t]{3}{*}{ Tebengau } & 60 & 53.31 & 23.72 & 40 \\
\hline & 120 & 79.46 & 50.40 & 42 \\
\hline & 180 & 93.02 & 68.63 & 38 \\
\hline
\end{tabular}

Source: Choudhury (2000).

at the International Fertilizer Development Centre (IFDC), United States of America. The superiority of USG over PU in rice culture has been found in many investigations (Roy, 1988; Craswell et al., 1985). Urea large granule (ULG), another modified form of urea having an average diameter of $7 \mathrm{~mm}$, has been developed in the Netherlands. This modified form of urea, because of its larger granule size than PU, may go deep into the mud simply by force throwing, and thus may be expected to be more efficient than PU. Azollon, a slow release nitrogen fertilizer, has been developed in Germany. It is a urea-formaldehyde condensation product containing 
$38 \%$ N. A field experiment was conducted on a clay loam soil at BRRI to evaluate the relative performances of PU, ULG, USG and azollon in wetland rice culture (Choudhury et al., 1994a). Considering grain yield, USG was significantly superior to PU and azollon; whereas, ULG had a slight edge over PU, but statistically not significantly different (Table 5). Total $\mathrm{N}$ uptake increased significantly in ULG and USG treated plots compared to the conventional PU treated plots. Agronomic efficiency and apparent recovery of added $\mathrm{N}$ were considerably higher with USG and ULG as compared to PU. Azollon was inferior to PU.

The increase in fertilizer $\mathrm{N}$ use efficiency due to the use of modified forms of urea will reduce environmental pollution problems like eutrophication (over enrichment in nutrients), production of greenhouse gases like nitrous oxide and nitrate toxicity in the ground water. However, these modified forms of urea are not commonly used by farmers. Farmers' awareness of environmental benefits of these practices should be created at farm level in order to use USG and ULG for rice production.

Methods of nitrogen fertilizer application. Generally, urea is applied as surface broadcasting which causes losses of urea by different mechanisms, and thereby $\mathrm{N}$ use efficiency becomes low. Sub-surface placement of $\mathrm{N}$ fertilizer into the anaerobic soil zone has been proposed by many investigators as a possible mean of increasing $\mathrm{N}$ use efficiency (Reddy and Mitra, 1985). Pneumatic urea injector, an instrument for deep placement of prilled urea, has been developed in the Netherlands. Prilled urea (PU) can be placed through injection by this instrument with necessary calibration into a depth of 8-10 $\mathrm{cm}$. A field experiment was conducted on a clay loam soil at BRRI to evaluate the relative performance of PU surface broadcasting and $\mathrm{PU}$ injection for $\mathrm{N}$ use efficiency in wetland rice culture
(Choudhury and Bhuiyan, 1994). In the surface broadcasting method, PU was applied in three equal splits $(1 / 3$ immediately after seedling establishment $+1 / 3$ at active tillering stage $+1 / 3$ at 5-7 days before panicle initiation); while in the injection method, PU was applied at a time immediately after seedling establishment. Three rates of $\mathrm{N}(29,58$ and $87 \mathrm{~kg} \mathrm{~N} / \mathrm{ha})$ were used in both methods of $\mathrm{N}$ application. A nitrogen control treatment was also used in the trial. The injection method gave higher grain yield over the surface broadcasting method at all the rates of applied $\mathrm{N}$, however, the difference was significant only at $87 \mathrm{~kg} \mathrm{~N} / \mathrm{ha}$ (Table 6). Straw yield and total $\mathrm{N}$ uptake were significantly higher with the injection method over the surface broadcasting method at all the rates of added N. Agronomic efficiency and apparent recovery of added $\mathrm{N}$ were considerably higher with the injection method.

Although deep place of PU is time consuming and laborious, this will reduce environmental problems by minimizing $\mathrm{N}$ fertilizer losses by volatilisation and denitrification in addition to increase in rice yield. Adoption of this technique at farm level by proper demonstration is necessary.

Nitrogen and sulphur interactions. Sulphur (S) is a secondary nutrient for all crops. The metabolism of $\mathrm{N}$ and $\mathrm{S}$ in plants is closely interrelated. As a result plant cannot utilize $\mathrm{N}$ properly in $\mathrm{S}$ deficient soils and conversely $\mathrm{S}$ utilization of plant is being adversely affected by $\mathrm{N}$ deficiency in soils (Shah et al., 1996). A field experiment was conducted on a silty clay soil at BRRI to study the synergistic effects of $\mathrm{N}$ and $\mathrm{S}$ on growth and yield of wetland rice (Choudhury et al., 1994b). A strong synergistic effect between $\mathrm{N}$ and $\mathrm{S}$ was observed (Table 7). At $0 \mathrm{~kg} \mathrm{~N} / \mathrm{ha}, \mathrm{S}$ application at $20 \mathrm{~kg} / \mathrm{ha}$ increased grain yield by only $0.3 \mathrm{t} / \mathrm{ha}$, while the same $\mathrm{S}$ rate increased grain yield by $0.9 \mathrm{t} / \mathrm{ha}$ at

Table 5. Effects of forms and sources of nitrogen fertilizer on grain yield of BR3 rice, total $\mathrm{N}$ uptake, agronomic efficiency and apparent recovery of added $\mathrm{N}$

\begin{tabular}{llllll}
\hline \hline $\begin{array}{l}\mathrm{N} \text { rate } \\
(\mathrm{kg} / \mathrm{ha})\end{array}$ & $\begin{array}{l}\mathrm{N} \text { fertilizer } \\
\text { form/source }\end{array}$ & $\begin{array}{l}\text { Grain yield } \\
(\text { tonnes/ha) }\end{array}$ & $\begin{array}{l}\text { Total N uptake } \\
(\mathrm{kg} / \mathrm{ha})\end{array}$ & $\begin{array}{l}\text { Agronomic efficiency } \\
(\mathrm{kg} \text { grain/kg added N) }\end{array}$ & $\begin{array}{l}\text { Apparent recovery } \\
\text { of added N }(\%)\end{array}$ \\
\hline 0 & - & $2.9^{\mathrm{d}}$ & $36.7^{\mathrm{e}}$ & - & - \\
87 & Prilled urea & $4.0^{\mathrm{b}}$ & $62.6^{\mathrm{c}}$ & 12.6 & 29.8 \\
87 & Urea large granule & $4.4^{\mathrm{ab}}$ & $70.3^{\mathrm{b}}$ & 17.2 & 38.6 \\
87 & Urea super granule & $4.6^{\mathrm{a}}$ & $91.0^{\mathrm{a}}$ & 19.5 & 62.4 \\
87 & Azollon & $3.6^{\mathrm{c}}$ & $53.0^{\mathrm{d}}$ & 8.1 & 18.7 \\
\hline \hline
\end{tabular}

Values followed by different letters within a column are significantly different at 5\% level by Duncan's Multiple Range Test (DMRT); source: Choudhury et al. (1994a). 
Table 6. Effects of rates and methods of nitrogen fertilizer application on grain and straw yields of BR3 rice, total $\mathrm{N}$ uptake, agronomic efficiency and apparent recovery of added $\mathrm{N}$

\begin{tabular}{lllllll}
\hline \hline $\begin{array}{l}\text { N rate } \\
(\mathrm{kg} / \mathrm{ha})\end{array}$ & $\begin{array}{l}\text { Method of } \\
\text { application* }\end{array}$ & $\begin{array}{l}\text { Grain yield } \\
(\mathrm{t} / \mathrm{ha})\end{array}$ & $\begin{array}{l}\text { Straw yield } \\
(\mathrm{t} / \mathrm{ha})\end{array}$ & $\begin{array}{l}\text { Total N uptake } \\
(\mathrm{kg} / \mathrm{ha})\end{array}$ & $\begin{array}{l}\text { Agronomic efficiency } \\
(\mathrm{kg} \text { grain/kg added N) }\end{array}$ & $\begin{array}{l}\text { Apparent recovery } \\
\text { of added N }(\%)\end{array}$ \\
\hline 0 & - & 2.7 & 1.8 & 35.9 & - & - \\
29 & $\mathrm{SB}$ & 3.3 & 2.0 & 44.3 & 20.7 & 29 \\
58 & $\mathrm{SB}$ & 3.6 & 2.3 & 49.8 & 15.5 & 24 \\
87 & $\mathrm{SB}$ & 4.0 & 2.6 & 55.9 & 14.9 & 23 \\
29 & $\mathrm{I}$ & 3.7 & 2.5 & 51.4 & 34.5 & 40 \\
58 & $\mathrm{I}$ & 4.0 & 2.8 & 59.2 & 22.4 & 39 \\
87 & $\mathrm{I}$ & 4.6 & 3.4 & 69.9 & 21.8 & - \\
\end{tabular}

*SB = surface broadcasting; I = injection; source: Choudhury and Bhuiyan (1994).

Table 7. Effects of nitrogen and sulphur on grain yield of BR3 rice and agronomic efficiency of added $\mathrm{N}$

\begin{tabular}{|c|c|c|c|c|}
\hline \multirow{2}{*}{$\begin{array}{l}\mathrm{N} \text { rate } \\
(\mathrm{kg} / \mathrm{ha})\end{array}$} & \multicolumn{3}{|c|}{ Sulphur rate (kg/ha) } & \multirow[t]{2}{*}{ Mean } \\
\hline & $\overline{0}$ & 20 & 40 & \\
\hline \multicolumn{5}{|c|}{ Grain yield (tonnes/ha) } \\
\hline 0 & 2.9 & 3.2 & 3.2 & $3.1 \mathrm{c}$ \\
\hline 60 & 4.0 & 4.1 & 4.2 & $4.1 \mathrm{~b}$ \\
\hline 120 & 4.1 & 5.0 & 5.2 & $4.8 \mathrm{a}$ \\
\hline Mean & $3.7 \mathrm{~b}$ & $4.1 \mathrm{a}$ & $4.2 \mathrm{a}$ & \\
\hline \multicolumn{5}{|c|}{ Agronomic efficiency of $\mathrm{N}^{1}$} \\
\hline 60 & 18.3 & 20.0 & 21.7 & 20.0 \\
\hline 120 & 10.0 & 17.5 & 19.2 & 15.6 \\
\hline Mean & 14.2 & 18.8 & 20.5 & \\
\hline
\end{tabular}

Kg grain per $\mathrm{kg}$ added $\mathrm{N}$ compared to the plots those received neither $\mathrm{N}$ nor $\mathrm{S}$; in a row/column, values followed by different letters are significantly different at $5 \%$ level by DMRT; source: Choudhury et al. (1994b).

$120 \mathrm{~kg} \mathrm{~N} / \mathrm{ha}$. Similarly at $0 \mathrm{~kg} \mathrm{~S} / \mathrm{ha}, \mathrm{N}$ application at $120 \mathrm{~kg} / \mathrm{ha}$ increased grain yield by $1.2 \mathrm{t} / \mathrm{ha}$, while the same $\mathrm{N}$ rate increased grain yield by $1.8 \mathrm{t} / \mathrm{ha}$ at $20 \mathrm{~kg}$ $\mathrm{S} /$ ha. Agronomic efficiency of added $\mathrm{N}$ increased gradually with increasing $\mathrm{S}$ rates up to $40 \mathrm{~kg} \mathrm{~S} / \mathrm{ha}$.

In $\mathrm{S}$ deficient soils, combined application of $\mathrm{N}$ and $\mathrm{S}$ is necessary to optimize grain yield. Investigations in India showed that combined application of $\mathrm{N}$ and $\mathrm{S}$ increased $\mathrm{N}$ and $\mathrm{S}$ uptakes by rice significantly (Srivastava and Singh, 2007). This implies that interactions between $\mathrm{N}$ and $\mathrm{S}$ have large effects on $\mathrm{N}$ and $\mathrm{S}$ transfers to rice plants for increasing grain production. Generally farmers are not using $\mathrm{S}$ fertilizer for rice. Awareness should be grown at farm level for the benefit $\mathrm{S}$ fertilisation in $\mathrm{S}$ deficient soils for increasing $\mathrm{N}$ use efficiency in rice production.

Varietal difference in nitrogen response. The magnitude of $\mathrm{N}$ response may vary from variety to variety depending upon their agronomic traits like plant height and growth duration in addition to $\mathrm{N}$ fertility status of the soil. Therefore, variety and soil specific $\mathrm{N}$ fertilizer recommendation is necessary to get optimum yield (Saleque et al., 2004). Agronomic efficiency (kg grain $/ \mathrm{kg}$ added $\mathrm{N}$ ) varies among rice varieties (Table 8). Nitrogen fertilizer requirement for maximum grain yield varies among varieties (Choudhury et al., 2002). Nitrogen rate for the maximum yield of a rice variety can be estimated from the regression equation $\mathrm{Y}=\mathrm{a}+\mathrm{bx}-\mathrm{cx}^{2}$ as follows (Gomez and Gomez, 1984):

$$
\mathrm{Ny}=\mathrm{b} / 2 \mathrm{c}
$$

where, $\mathrm{Ny}=\mathrm{N}$ rate $(\mathrm{kg} / \mathrm{ha})$ for maximum yield. Determination of $\mathrm{N}$ rates for maximum grain yields of different varieties is necessary to avoid indiscriminate application of a single $\mathrm{N}$ rate for all the varieties. This information will help to reduce $\mathrm{N}$ fertilizer losses through indiscriminate application of $\mathrm{N}$ and thus reduces environmental pollution to some extent.

Nitrogen response of short and tall statured varieties. Nitrogen response may vary among rice varieties based on their plant stature in addition to growth duration. A field experiment was conducted using four rice varieties (BR1, BR3, BR14 and BRRIdhan 29) having different agronomic parameters (Table 9) in a clay soil at BRRI farm in 1993 (BRRI, 1996). BR1 and BR14 are short duration varieties, while BR3 and BRRIdhan 29 are long duration ones. Again heights of BR1 and BR3 were relatively shorter than BR14 and BRRIdhan 29. Number 
Table 8. Grain yield of some modern rice varieties without and with fertilizer N

\begin{tabular}{llllll}
\hline \hline Rice variety & \multicolumn{3}{c}{ Grain yield (t/ha) } & $\begin{array}{l}\text { Agronomic } \\
\text { efficiency** }\end{array}$ & Reference \\
\cline { 2 - 4 } & $\begin{array}{l}\text { Without } \\
\text { fertilizer N }\end{array}$ & $\begin{array}{l}\text { With fertilizer N } \\
(120 \mathrm{~kg} \mathrm{~N} / \mathrm{ha})\end{array}$ & Difference* & & \\
\hline BR1 & 2.60 & 4.70 & 2.10 & 17.50 & Choudhury et al., 1997a \\
BR3 & 2.60 & 4.80 & 2.20 & 18.33 & Choudhury et al., 1997a \\
BR14 & 3.00 & 5.20 & 2.20 & 18.33 & Choudhury et al., 1997a \\
BR22 & 2.50 & 4.30 & 1.80 & 15.00 & Choudhury et al. $1997 \mathrm{~b}$ \\
BR25 & 3.10 & 5.10 & 2.00 & 16.67 & Choudhury et al. $1997 \mathrm{~b}$ \\
BRRIdhan 29 & 3.60 & 5.90 & 2.30 & 19.17 & Choudhury et al., 1997a \\
\hline \hline
\end{tabular}

$*=$ differences were statistically significant at $5 \%$ probability level; $* *=\mathrm{kg}$ grain per $\mathrm{kg}$ added $\mathrm{N}$.

of tiller as well as panicle production per unit area was the highest in BR1 followed by BRRIdhan 29, BR3 and the lowest in BR14. Six rates of $N(0,40,80,120$, 160 and $200 \mathrm{~kg} \mathrm{~N} / \mathrm{ha}$ ) were used in the experiment. Grain yield response to added $\mathrm{N}$ varied among the varieties (Table 10). The most interesting finding is that the tall statured varieties (BR14 and BRRIdhan 29) out yielded the short statured ones (BR1 and BR3) in N control plots by 0.4 to $0.6 \mathrm{t} / \mathrm{ha}$. This indicates that the

Table 9. Some agronomic parameters of four modern rice varieties

\begin{tabular}{lllll}
\hline \hline Variety & $\begin{array}{l}\text { Plant } \\
\text { height } \\
(\mathrm{cm})\end{array}$ & $\begin{array}{l}\text { Growth } \\
\text { duration } \\
(\text { days })\end{array}$ & $\begin{array}{l}\text { Tiller } \\
\text { number } / \mathrm{m}^{2}\end{array}$ & $\begin{array}{l}\text { Panicle } \\
\text { number } / \mathrm{m}^{2}\end{array}$ \\
\hline BR1 & 63 & 150 & 414 & 404 \\
BR3 & 79 & 170 & 302 & 291 \\
BR14 & 91 & 155 & 263 & 247 \\
BRRIdhan 29 & 90 & 168 & 310 & 296 \\
\hline \hline
\end{tabular}

* = period started from date of nursery sowing; source: BRRI, (1996).

Table 10. Effect of $\mathrm{N}$ fertilisation on grain yield of four modern rice varieties

\begin{tabular}{lllll}
\hline \hline \multirow{2}{*}{$\begin{array}{l}\text { N rate } \\
(\mathrm{kg} / \mathrm{ha})\end{array}$} & \multicolumn{4}{c}{ Grain yield (t/ha) } \\
\cline { 2 - 5 } & BR1 & BR3 & BR14 & BRRIdhan 29 \\
\hline 0 & $2.6^{\mathrm{d} \mathrm{B}}$ & $2.6^{\mathrm{d} \mathrm{B}}$ & $3.0^{\mathrm{d} \mathrm{AB}}$ & $3.2^{\mathrm{cA}}$ \\
40 & $3.4^{\mathrm{c} \mathrm{BC}}$ & $3.2^{\mathrm{c} \mathrm{C}}$ & $3.7^{\mathrm{c} \mathrm{B}}$ & $4.7^{\mathrm{b} \mathrm{A}}$ \\
80 & $3.7^{\mathrm{c} \mathrm{C}}$ & $4.2^{\mathrm{b} \mathrm{BC}}$ & $4.3^{\mathrm{b} \mathrm{B}}$ & $5.3^{\mathrm{aA}}$ \\
120 & $4.7^{\mathrm{b} \mathrm{B}}$ & $4.8^{\mathrm{a} \mathrm{B}}$ & $5.2^{\mathrm{a} \mathrm{AB}}$ & $5.4^{\mathrm{a} \mathrm{A}}$ \\
160 & $5.3^{\mathrm{a} \mathrm{AB}}$ & $5.0^{\mathrm{a} \mathrm{B}}$ & $5.3^{\mathrm{aA}}$ & $5.6^{\mathrm{aA}}$ \\
200 & $5.1^{\mathrm{ab} \mathrm{B}}$ & $5.2^{\mathrm{aAB}}$ & $5.2^{\mathrm{aAB}}$ & $5.7^{\mathrm{aA}}$
\end{tabular}

Source: BRRI (1996); figures followed by a common letter within a column (small letter) or row (capital letter) are not significantly different at 5\% level by Duncan's Multiple Range Test (DMRT). tall statured varieties can exploit more soil $\mathrm{N}$ for grain production. Root mass density was relatively higher in tall statures varieties (BR14 and BRRIdhan 29) compared to short statured ones (BR1 and BR3) at 10-20 cm depth in $\mathrm{N}$ control plots (Table 11). This implies that having deeper root system the tall varieties were able to utilize more soil $\mathrm{N}$ for grain production compared to the short ones in $\mathrm{N}$ control plots which enabled them to produce extra grain without fertilizer input. So, modern rice varieties having relatively taller plant stature will be economically advantageous for marginal farmers to produce extra grain without fertilizer input.

Table 11. Effect of $\mathrm{N}$ fertilization on root mass density of four modern rice varieties at flowering stage

\begin{tabular}{llllll}
\hline \hline $\begin{array}{l}\text { N rate } \\
(\mathrm{kg} / \mathrm{ha})\end{array}$ & \multicolumn{5}{c}{ Root mass density $\left(\mathrm{mg} / \mathrm{cm}^{3}\right)$} \\
\cline { 2 - 6 } & BR1 & BR3 & BR14 & $\begin{array}{l}\text { BRRI } \\
\text { dhan 29 }\end{array}$ & N Mean \\
\hline \multicolumn{5}{c}{$0-10 \mathrm{~cm}$ depth } \\
0 & 1.10 & 2.50 & 1.98 & 2.15 & $1.93^{\mathrm{d}}$ \\
40 & 1.35 & 3.22 & 2.47 & 2.44 & $2.37^{\mathrm{cd}}$ \\
80 & 1.56 & 3.35 & 3.02 & 2.61 & $2.64^{\mathrm{bc}}$ \\
120 & 1.86 & 3.43 & 3.50 & 2.88 & $2.92^{\mathrm{ab}}$ \\
160 & 2.05 & 3.49 & 3.54 & 3.07 & $3.04^{\mathrm{ab}}$ \\
200 & 2.12 & 4.13 & 3.84 & 3.57 & $3.42^{\mathrm{a}}$ \\
Variety mean & $1.67^{\mathrm{B}}$ & $3.3^{\mathrm{A}}$ & $3.06^{\mathrm{A}}$ & $2.79^{\mathrm{A}}$ & - \\
\cline { 2 - 6 } & \multicolumn{5}{c}{$10-20 \mathrm{~cm}$ depth } \\
0 & 0.06 & 0.08 & 0.10 & 0.16 & $0.10^{\mathrm{b}}$ \\
40 & 0.07 & 0.15 & 0.17 & 0.18 & $0.14^{\mathrm{ab}}$ \\
80 & 0.11 & 0.17 & 0.17 & 0.19 & $0.16^{\mathrm{a}}$ \\
120 & 0.12 & 0.14 & 0.15 & 0.18 & $0.15^{\mathrm{ab}}$ \\
160 & 0.04 & 0.13 & 0.13 & 0.15 & $0.11^{\mathrm{ab}}$ \\
200 & 0.03 & 0.11 & 0.10 & 0.15 & $0.10^{\mathrm{b}}$ \\
Variety mean & $0.07^{\mathrm{B}}$ & $0.13^{\mathrm{AB}}$ & $0.14^{\mathrm{A}}$ & $0.17^{\mathrm{A}}$ & - \\
\hline \hline
\end{tabular}

Source: BRRI (1996); figures followed by a common letter within a column (small letter) or row (capital letter) are not significantly different at $5 \%$ level by DMRT. 
Nitrogen response of traditional and improved plant types. A field experiment was conducted on a clay soil at BRRI during 1994 to evaluate the $\mathrm{N}$ response behaviour of four rice varieties (NigerSail, BR22, Pajam and BR25) using six $\mathrm{N}$ rates $(0,30,60,90,120$ and $150 \mathrm{~kg} \mathrm{~N} / \mathrm{ha}$ ) in wetland culture (Choudhury et al., 1997b). The variety BR22 is the improved plant type of Niger-Sail while BR25 is the improved plant type of Pajam. Grain yield response to added $\mathrm{N}$ varied among the varieties (Table 12). While, NigerSail responded to added $\mathrm{N}$ up to $90 \mathrm{~kg} \mathrm{~N} / \mathrm{ha}$, its improved plant type BR22 responded up to $150 \mathrm{~kg} \mathrm{~N} / \mathrm{ha}$. Both Pajam and its improved plant type BR25 responded up to $120 \mathrm{~kg}$ N/ha. However, BR25 out yielded Pajam at all the rates of added $\mathrm{N}$. Regression analysis indicated that the estimated response function between $\mathrm{N}$ rate and grain yield for all the varieties was quadratic in nature (Table 13).

Table 12. Effects of $\mathrm{N}$ fertilization on grain yield of four rice varieties

\begin{tabular}{lllll}
\hline \hline \multirow{2}{*}{$\begin{array}{l}\text { N rate } \\
(\mathrm{kg} / \mathrm{ha})\end{array}$} & \multicolumn{4}{c}{ Grain yield (t/ha) } \\
\cline { 2 - 5 } & NigerSail & BR22 & Pajam & BR25 \\
\hline 0 & 2.6 & 2.5 & 3.0 & 3.1 \\
30 & 3.2 & 3.5 & 3.7 & 3.9 \\
60 & 3.3 & 3.8 & 4.0 & 4.7 \\
90 & 3.6 & 4.0 & 4.3 & 4.8 \\
120 & 3.3 & 4.3 & 4.8 & 5.1 \\
150 & 3.2 & 4.7 & 4.8 & 4.9 \\
\hline \hline
\end{tabular}

Source: Choudhury et al. (1997b).

Table 13. Regression equation and $\mathrm{R}^{2}$ value relating grain yield and $\mathrm{N}$ rate for four rice varieties

\begin{tabular}{llll}
\hline \hline Variety & Regression equation & $\begin{array}{l}\mathrm{R}^{2} \\
\text { value }\end{array}$ & $\begin{array}{l}\text { Estimated N } \\
\text { rate }(\mathrm{kg} / \mathrm{ha}) \\
\text { for maximum } \\
\text { yield }\end{array}$ \\
\hline NigerSail & $\mathrm{y}=2.681+0.018 \mathrm{x}-0.0001 \mathrm{x}^{2}$ & $0.86^{*}$ & 90 \\
BR22 & $\mathrm{y}=2.626+0.023 \mathrm{x}-0.0001 \mathrm{x}^{2}$ & $0.96^{* *}$ & 115 \\
Pajam & $\mathrm{y}=3.002+0.021 \mathrm{x}-0.0001 \mathrm{x}^{2}$ & $0.98^{* *}$ & 105 \\
BR25 & $\mathrm{y}=3.119+0.032 \mathrm{x}-0.0001 \mathrm{x}^{2}$ & $0.98^{* *}$ & 160 \\
\hline \hline
\end{tabular}

$*=$ significant at $10 \%$ level of probability; $* *=$ significant at 1\% level of probability; source: Choudhury et al. (1997b).

However, the rate of response as evidenced from the response co-efficient (b value) was higher in the improved plant types (BR22 and BR25) compared to their respective traditional plant types (NigerSail and
Pajam). While, the b value was only 0.018 for NigerSail, it was 0.023 for its improved plant type BR22. Again the $b$ value for Pajam was 0.021 against the $b$ value of 0.032 for its improved plant type BR25. The b value is the slope of regression line which measures the estimated rate of response (either increase or decrease). This implies that improved plant type can utilize fertilizer $\mathrm{N}$ more efficiently for grain production compared to their respective traditional plant type. Estimated $\mathrm{N}$ rate for maximum yield varies among the varieties. Estimated $\mathrm{N}$ rates for maximum grain yield were 160, 115, 105 and $90 \mathrm{~kg} / \mathrm{ha}$ for BR25, BR22, Pajam and NigerSail, respectively. This information implies that there are differences among rice varieties for $\mathrm{N}$ requirement for maximum grain production.

\section{Conclusion}

Nitrogen use efficiency in rice culture can be increased considerably by using modified forms of urea like USG and ULG. The efficiency of the conventional prilled urea in rice culture can be increased to some extent by injecting it into the sub-surface by the instrument "Pneumatic Urea Injector". In sulphur deficient soils, $\mathrm{N}$ use efficiency in rice culture can be increased by combined application of $\mathrm{N}$ and $\mathrm{S}$. Modern rice varieties having relatively taller plant stature will be economically advantageous for marginal farmers to produce extra grain without fertilizer input. There are varietal differences for $\mathrm{N}$ requirement for maximum grain production. This information will be helpful to avoid indiscriminate application of a single $\mathrm{N}$ rate for all the varieties. These ways of increasing $\mathrm{N}$ use efficiency will reduce environmental pollution problems due to eutrophication (over enrichment in nutrients), production of greenhouse gases like nitrous oxide, and nitrate toxicity in the ground water.

\section{References}

Baldani, V.L.D., Baldani, J.I., Döbereiner, J. 2000. Inoculation of rice plants with the endophytic diazotrophs Herbaspirillum seropodicae and Burkholderia spp. Biology and Fertility of Soils, 30: 485-491.

BRRI, 1996. Annual Report for 1996, Bangladesh Rice Research Institute, Gazipur, Bangladesh.

BRRI. 1993. Annual Report for 1993, Bangladesh Rice Research Institute, Gazipur, Bangladesh.

Chen, Y., Wu, C., Tang, X., Yang, S., Wang, J. 2010. Fate of nitrogen from organic and inorganic sources 
in rice-wheat rotation cropping system. Agricultural Sciences in China, 9: 1017-1025.

Choudhury, A.T.M.A., Kennedy, I.R. 2005. Nitrogen fertilizer losses from rice soils and control of environmental pollution problems. Communications in Soil Science and Plant Analysis, 36: 1625-1639.

Choudhury, A.T.M.A., Zaman, S.K., Bhuiyan, N.I., 2002. Nitrogen fertilizer requirement of three modern rice varieties for maximum yield. In: Proceedings of the Second International Conference on Sustainable on Agriculture for Food, Energy and Industry, L. Dajue (ed.), pp. 1454-1457, Institute of Botany, Chinese Academy of Sciences, Beijing, China.

Choudhury, A.T.M.A. 2000. Adjusting N, K, Mg and $\mathrm{Cu}$ Rates for Improvement of Fertilizer N Use Efficiency in Rice Production in Malaysia. Ph.D Thesis, Universiti Putra Malaysia, Selangor, Malaysia.

Choudhury, A.T.M.A., Zaman, S.K., Bhuiyan, N.I. 1997a. Nitrogen response behavior of modern rice varieties with different agronomic traits. Thai Journal of Agricultural Science, 30: 185-193.

Choudhury, A.T.M.A., Zaman, S.K., Bhuiyan, N.I. 1997b. Nitrogen response behavior of four rice varieties under wetland culture. Thai Journal of Agricultural Science, 30: 195-202.

Choudhury, A.T.M.A., Bhuiyan, N.I. 1994. Effect of rates and methods of nitrogen application on grain yield and nitrogen uptake of wetland rice. Pakistan Journal of Scientific and Industrial Research, 37: 104-107.

Choudhury, A.T.M.A., Bhuiyan,N.I., Hashem, M.A., Matin, M.A. 1994a. Nitrogen fertilizer management in wetland rice culture. Thai Journal Agricultural Science, 27: 259-267.

Choudhury, A.T.M.A., Shah, A.L., Rahman, M.S., Zaman, S.K., Bhuiyan, N.I. 1994b. Synergistic effect of nitrogen and sulphur in wetland rice. Progressive Agriculture, 5: 183-187.

Choudhury, A.T.M.A., Zaman, S.K., Bhuiyan, N.I. 1994c. Evaluation of mixed and complex fertilizers for wetland rice. Pakistan Journal of Scientific and Industrial Research, 37: 378-381.

Choudhury, A.T.M.A., Zaman, S.K., Bhuiyan, N.I. 1992. Evaluation of multinutrient fertilizers for wetland rice (in Bnagladesh). Bangladesh Journal of Soil Science, 23: 23-29.

Craswell, E.T., De Datta, S.K., Weeraratne, C.S., Vleck, P.L.G. 1985. Fate and efficiency of nitrogen fertilizers applied to wetland rice. Philippines
Fertilizer Research, 6: 49-63.

Gomez, K. A., Gomez, A.A. 1984. Statistical Procedures for Agricultural Research, 680 pp., $2^{\text {nd }}$ edition, John Wiley and Sons, Inc., New York, USA.

Hakeem, K.R., Ahmad, A., Iqbal, M., Gucel, S., Ozturk, M. 2011. Nitrogen-efficient rice cultivars can reduce nitrate pollution. Environmental Science and Pollution Research, 18: 1184-1193.

Hashem, M.A. 2001. Problems and prospects of cyanobacterial biofertilizer for rice cultivation. Australian Journal of Plant Physiology, 28: 881888.

IFA, 2011. International Fertiliser Industry Association, http://www.fertilizer.org/ifa/ifadata

IRRI, 2011. International Rice Research Institute, http://irri.org/our-science/social-sciences-economics/world-rice-statistics

Mai, V.T., Keulen, H.V., Roetter, R. 2010. Nitrogen leaching in intensive cropping systems in Tam Duong District, Red River Delta of Vietnam. Water, Air and Soil Pollution, 210: 15-31.

Reddy, M.D., Mitra, B.N. 1985. Responses of rice to different forms of urea and phosphorus fertilization under intermediate deepwater conditions. Plant and Soil, 84: 431-435.

Reeves, T.G., Waddington, S.R., Ortiz-Monasterio, I., Bänziger, M., Cassady, K.. 2002. Removing nutritional limits to maize and wheat production: A developing country perspective. In: Biofertilisers in Action, I.R. Kennedy and A.T.M.A. Choudhury (eds.), pp.11-36, Rural Industries Research and Development Corporation, Canberra, Australia.

Roy, B. 1988. Coated and modified urea materials for increasing nitrogen use efficiency of lowland rice in heavy clay soil. Fertilizer Research, 15: 101-109.

Sahrawat, K.L. 2000. Macro and micronutrients removed by upland and lowland rice cultivars in West Africa. Communications in Soil Science and Plant Analysis, 31: 717-723.

Saleque, M.A., Naher, U.A., Choudhury, N.N., Hossain, A.T.M.S. 2004. Variety-specific nitrogen fertilizer recommendation for lowland rice. Communications in Soil Science and Plant Analysis, 35: 1891-1903.

Sattar, M.A., Rahman, M.F., Das, D.K., Choudhury, A.T.M.A. 2008. Prospects of using Azotobacter, Azospirillum and Cyanobacteria as supplements of urea nitrogen for rice production in Bangladesh. In: Efficient Nutrient Use in Rice Production in Vietnam Achieved Using Inoculant Biofertilisers, Proceedings of Australian Centre for International 
Agricultural Research (ACIAR) No. 130, I. R. Kennedy, A. T. M. A. Choudhury, M. M. Keckes and M. T. Rose (eds.), pp. 59-66, ACIAR, Canberra, Australia.

Shah, A.L., Choudhury, A.T.M.A., Rahman, M.S., Bhuiyan, N.I. 1996. Nitrogen and sulphur interactions in wetland rice. Bangladesh Journal of Scientific Research, 14: 161-168.

Shrestha, R.K., Ladha, J.K. 1998. Nitrate in groundwater and integration of nitrogen-catch crop in rice-sweet pepper cropping system. Soil Science Society of America Journal, 62: 1610-1619.

Srivastava, P.C., Singh, U.S. 2007. Effect of graded levels of nitrogen and sulfur and their interaction on yields and quality of aromatic rice. Journal of
Plant Nutrition, 30: 811-828.

Wang, X., Suo, Y., Feng, Y., Shohag, M.J.I., Gao, J., Zhang, Q.C., Xie, S., Lin, X.Y. 2011. Recovery of ${ }^{15} \mathrm{~N}$-labeled urea and soil nitrogen dynamics as affected by irrigation management and nitrogen application rate in a double rice cropping system. Plant and Soil, 343: 195-2008.

Wang, Y., Zhu, B., Shi, Y., Hu, C. 2008. Effects of nitrogen fertilization on upland rice based on pot experiments. Communications in Soil Science and Plant Analysis, 39: 1733-1749.

Zhao, L., Wu, L., Dong, C., Li, Y. 2010. Rice yield, nitrogen utilization and ammonia volatilization as influenced by modified rice cultivation at varying nitrogen rates. Agricultural Sciences, 1: 10-16. 